\title{
Problemy rewitalizacji małych miast na przykładzie Międzyrzecza
}

\author{
Wanda Kononowicz, Ilona Pisera
}

Katedra Architektury i Urbanistyki, Wydziat Budownictwa, Architektury i Inżynierii Środowiska,

Uniwersytet Zielonogórski,e-mail:w.kononowicz@aiu.uz.zgora.pl,ilonapisera@gmail.com

Streszczenie: W artykule zaprezentowano metodę rewitalizacji Starego Miasta wraz z zamkiem i zespołem folwarcznym w Międzyrzeczu, zastosowaną w projekcie dyplomowym, wykonanym w 2016 roku na Uniwersytecie Zielonogórskim, w Katedrze Architektury i Urbanistyki [1]. Projekt ten został wyróżniony w międzynarodowym konkursie konserwatorskim im. Prof. Jana Zachwatowicza, organizowanym dorocznie przez PKN ICOMOS, a także zdobył nagrodę w Konkursie o Nagrodę Ministra Infrastruktury [2]. Metoda rewitalizacji polegała na przywróceniu generalnych cech przestrzennej struktury średniowiecznego miasta, przy dopuszczalnej różnorodności elementów drugoplanowych kompozycji. Pojęcie różnorodności odnosi się tu zarówno do obiektów objętych ochroną konserwatorską, jak też do nowoprojektowanych o nowoczesnej formie, harmonizującej z otoczeniem, a także rekonstruowanych.

Wschodnia pierzeja rynku jak i duża część pierzei południowej, uległy zniszczeniu na skutek II wojny światowej i nigdy nie zostały odbudowane, a ich miejsce oraz sąsiadujących kwartałów zabudowy wypełniła zieleń. Większość mieszkańców, szczególnie młodych, akceptuje taki stan.

Projekt stanowi przykład kompleksowego opracowania konserwatorskiego od skali urbanistycznej do architektonicznej, Wykonane studium historyczno-urbanistyczne oraz staranne analizy stanu istniejącego, w różnych aspektach pozwoliły skonstruować wytyczne konserwatorskie, które dały podstawę do projektu rewitalizacji historycznego miasta. W ramach rewitalizacji, m.in. uzupełniono strukturę miejską o brakujące kwartały zabudowy, przywrócono Rynkowi jego rangę i historyczne proporcje, zaprojektowano nową posadzkę w Rynku, ożywiono nową funkcją zabudowania folwarczne oraz zaprojektowano park krajobrazowy na sąsiadującym zdegradowanym terenie.

Słowa kluczowe: rewitalizacja, małe miasta, Międzyrzecz.

\section{Wprowadzenie}

Ochrona małych miast historycznych, w tym miast małych, jako dobra kultury, ma już swoją tradycję, zapoczątkowaną II Międzynarodowym Kongresem Architektów i Techników Zabytków, który miał miejsce w Wenecji w 1964 roku. W dokumencie końcowym tej konferencji, zwanym „Kartą Wenecką” stwierdzono, że pojęcie zabytku obejmuje nie tylko pojedyncze dzieła architektoniczne, ale także zespoły miejskie i wiejskie oraz miejsca będące świadectwem poszczególnych cywilizacji, ewolucji o doniosłym znaczeniu, bądź wydarzenia historycznego. Uzupełnieniem „Karty Weneckiej” w zakresie ochrony miast historycznych była tzw. „Rekomendacja Warszawska", ratyfikowana podczas Konferencji Generalnej UNESCO w Nairobi (1976) [2], [3], [4]. Przedsięwzięcia, które następowały w kolejnych latach, jak np. Europejska 
Kampania Ochrony Miast, podjęta przez Radę Europejską w 1981 roku, czy też opracowanie międzynarodowej karty ochrony miast historycznych ICOMOS, zwanej „Kartą Waszyngtońską" - (Toledo/Waszyngton, 1987), uzupełniały zakres i poszerzały spektrum ochrony zabytków urbanistyki. Podobnie istotne uzupełniające znaczenie miały: Deklaracja z Quebeck (2008) - w sprawie zachowania genius loci, także Zalecenia UNESCO w sprawie historycznego krajobrazu miejskiego - (Paryż 2011), jak również Dokument z La Valetty - w sprawie ochrony i zagospodarowania miast historycznych i dzielnic zabytkowych - (Paryż 2011) [3], [4].

Tematyka rewaloryzacji historycznych założeń urbanistycznych jest podejmowana na Wydziałach Architektury polskich uczelni od ponad dwóch dekad. Od grudnia 2000 roku PKN ICOMOS organizuje corocznie Międzynarodowy Konkurs im. Prof. Jana Zachwatowicza na najlepsze prace dyplomowe w dziedzinie badań i konserwacji zabytków [5]. W niniejszym artykule zaprezentowano projekt dyplomowy rewitalizacji Starego Miasta wraz z kompleksem zamkowym w Międzyrzeczu, wykonanym w Katedrze Architektury i Urbanistyki, który zdobył laury konkursie konserwatorskim ICOMOS, im. Prof. Jana Zachwatowicza (2016), a także w Konkursie o Nagrodę Ministra Infrastruktury za prace dyplomowe, rozprawy doktorskie i habilitacyjne oraz publikacje w dziedzinach architektury i budownictwa, planowania i zagospodarowania przestrzennego oraz mieszkalnictwa (2017) [1], [2].

\section{Historyczno-urbanistyczny zarys rozwoju miasta}

Początki Międzyrzecza związane są z grodziskiem drewniano ziemnym i osadą, powstałymi ok. IX w., na cyplu terenu, oblanym wodami rzek Paklicy i Obry. To tu w pobliżu grodu Bolesław Chrobry osadził braci zakonnych, znanych dziś jako „Pięciu Męczenników Polski”, którzy zginęli śmiercią męczeńską w 1003 r. Gród, który nosił nazwy Mezerici (wg kronikarza Thietmara) oraz Mestris (wg św. Brunona z Kwerfurtu) [6], był zniszczony przez Pomorzan i następnie odbudowany. Największych zniszczeń dokonał jednak najazd Fryderyka Barbarossy w 1157 roku. W XIII wieku powstaje tu kasztelania, a w jej sąsiedztwie miasto lokacyjne na prawie niemieckim. Duży wpływ na rozwój Międzyrzecza pod względem strategicznym i ekonomicznym miało położenie nad rzekami i przy ważnych szlakach handlowych.

W XIV wieku, za Kazimierza Wielkiego, miasto otoczono murami i wzniesiono murowany zamek, w ramach wzmocnienia zachodnich granic Polski. Centrum miasta stanowił rynek z murowanym ratuszem. Zabudowa mieszczańska w przeważającej mierze miała konstrukcję ryglową.

Pod koniec XVIII wieku miasto było jednym z najważniejszych ośrodków sukienniczych w Europie. Najsłynniejszym sukiennikiem był J. J. Volmer - właściciel kamienicy przy wschodniej pierzei Rynku, znacząco wyróżniającej się na tle drewnianej zabudowy. Po drugim rozbiorze Polski w 1793 roku miasto przeszło we władanie Prus.

Na prawym brzegu Obry leżała wieś Winnica, gdzie znajdował się folwark z gorzelnią, połączony nieistniejącą dziś przeprawą z resztą miasta. W okresie napoleońskim, od 1807 Międzyrzecz należał do Księstwa Warszawskiego. Murowana zabudowa pojawiła się w mieście dopiero w latach 30-tych XIX wieku, a z czasem zbudowano kolej i dokonano elektryfikacji [6].

Po I wojnie światowej, na mocy traktatu wersalskiego, miasto znów przypisano do Niemiec. W latach 30-tych XX wieku rozpoczęto budowę międzyrzeckiego rejonu umocnionego z siecią fortyfikacji podziemnych jako wzmocnienie wschodniej granicy Niemiec. 
Pod koniec II wojny światowej część zabudowy miejskiej została zburzona. Po wojnie kompleks zamkowy i dworski wraz założeniem parkowym przekształcono na muzeum. Zniszczone pierzeje zabudowy przyrynkowej, wschodnią i częściowo południową, rozebrano w latach 50-tych, a w miejscu kamienic utworzono park, który zmienił dotychczasowy charakter Rynku. Odbudowa miasta w dużym stopniu ignorowała wcześniejszy układ przestrzenny wprowadzając w sposób nieprzemyślany nową, dominującą zabudowę.

Zachowana zabudowa Starego Miasta, w przeważającej mierze pochodzi z XIX i XX wieku. Wyjątek stanowią: Zamek z XIV wieku, gotycki kościół św. Jana Chrzciciela z XIV wieku oraz dawna karczma dworska z XVII wieku, wchodząca w skład kompleksu zamkowego [1]. Ratusz, wzniesiony w połowie XVIII wieku był modernizowany i przebudowywany w XIX i w XX wieku, natomiast kościół św. Wojciecha (dawny zbór ewangelicki), stojący w północnej pierzei rynkowej, zbudowano w 30. latach XIX wieku.

\section{Założenia projektowe}

\subsection{Komunikacja}

Dzięki istniejącej drodze ekspresowej S3, której fragment stanowi zachodnią obwodnicę Międzyrzecza, centrum miasta zostało odciążone z ruchu na osi północ-południe. Rynek jest nadal obarczony ruchem na osi wschód-zachód. Aby wyeliminować największe natężenie ruchu zaprojektowano wschodnią obwodnicę Międzyrzecza, dzięki czemu samochody jadące ze wschodu na północ i południe zostaną skierowane na istniejącą obwodnicę S3. Przebiegającą przez rynek ul. Młyńską zdegradowano z drogi wojewódzkiej na gminną, tworząc ciąg pieszo-jezdny w obrębie rynku i wprowadzając strefę ograniczenia prędkości na starym mieście do $30 \mathrm{~km} / \mathrm{h}$.

\subsection{Rewitalizacja kompleksu zamkowego}

Kompleks zamkowy obejmuje tereny i obiekty zabytkowe leżące na lewym i prawym brzegu Obry. Lewobrzeżne założenie, z warownym zamkiem z czasów Kazimierza Wielkiego i dawnym domem starosty, funkcjonuje jako Muzeum Ziemi Międzyrzeckiej i stanowi prawdziwą atrakcję Międzyrzecza. Budowle te, jak i okalająca je zieleń parkowa są dobrze utrzymane i nie wymagają specjalnych zabiegów rewaloryzacyjnych. W projekcie uzupełniono zabudowę w rejonie dawnej karczmy, w południowej części terenu, budynkami o funkcji usługowej, w wachlarzowatym układzie.

Prawobrzeżna enklawa kompleksu zamkowego przedstawia diametralnie różny widok. Obejmuje bowiem mocno zdegradowany, podmokły teren z rozpadającymi się budynkami po dawnym folwarku, wśród niezagospodarowanych nieużytków (Rys. 1) Na zachód od zabudowań folwarcznych znajduje się rozległy, regularny staw (gospodarczy?), o powierzchni kilkukrotnie przekraczającej powierzchnię Rynku. Brzydoty obrazu dopełnia wyjątkowo nieestetyczna naziemna rura ciepłownicza, biegnąca przez cały teren, z północy na południe. 


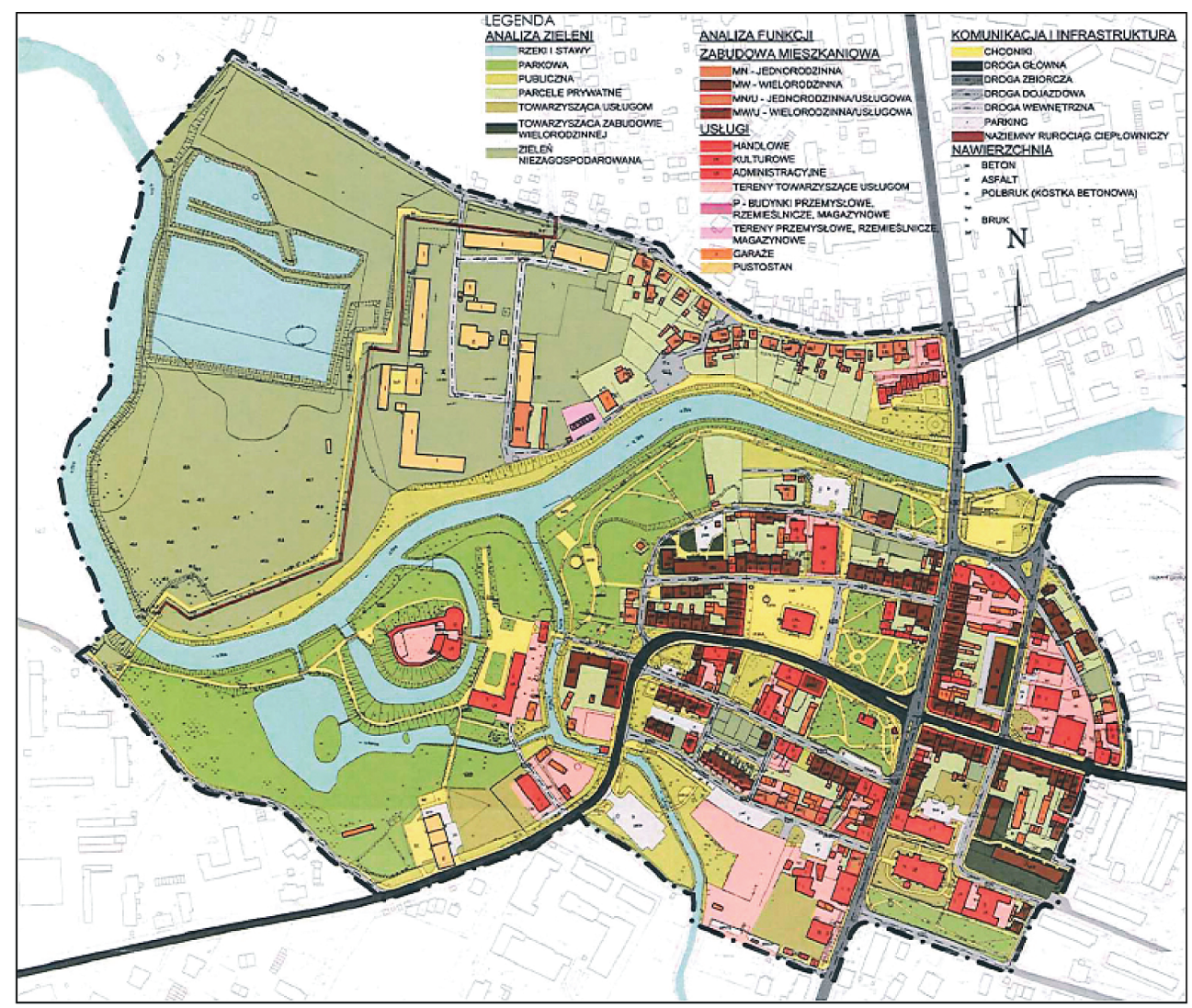

Rys. 1. Międzyrzecz, analiza funkcjonalna stanu istniejącego. Rys. Ilona Pisera

Zgodnie z koncepcją rewitalizacji budynki pofolwarczne w zmodernizowanej formie, będą pełniły nową funkcję - centrum edukacyjno-naukowego dla dzieci i młodzieży, gdzie znajdą się pracownie, sale dydaktyczne i konferencyjne. Obszerny dziedziniec natomiast służyć będzie celom wystawienniczym i organizowaniu imprez kulturalnych (Rys. 2).

Uwzględniając analizę hipsometryczną, zrewitalizowano także cały teren leżący na zachód od zabudowań folwarku i nadano mu nową funkcję. Usunięto naziemną rurę ciepłowniczą, zasypano staw i zaprojektowano park krajobrazowy, jako rezerwuar rekreacyjnej zieleni dla mieszkańców miasta. Za inspirację posłużył Birkenhead Park w Liverpoolu, romantyczny projekt Josepha Paxtona (1844), jeden z pierwszych, publicznych parków miejskich w Europie.

W projekcie przewidziano powiązanie obu części założenia, na lewym i prawym brzegu przez budowę nowego mostu na Obrze, w miejscu dawnego drewnianego, dziś nieistniejącego. Nowy most na osi łączącej plac przed Muzeum i dziedziniec centrum dydaktycznonaukowego ułatwi mieszkańcom dostęp do parku i nowych funkcji. 


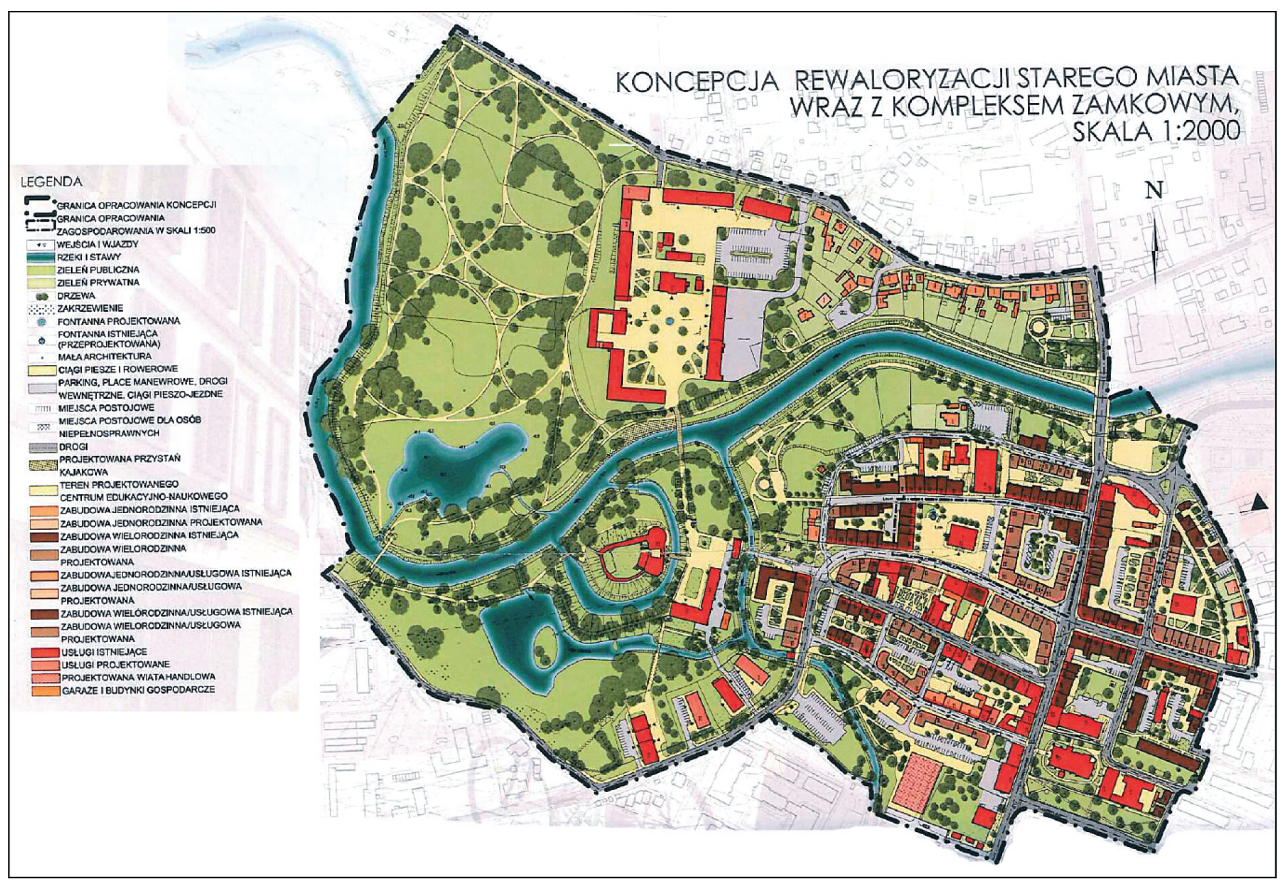

Rys. 2. Międzyrzecz, koncepcja rewaloryzacji historycznego miasta wraz z kompleksem zamkowym. Rys. Ilona Pisera

\subsection{Rewitalizacja Starego Miasta}

Głównym i najważniejszym założeniem zaprezentowanej koncepcji jest restrukturalizacja, czyli odbudowa struktur przestrzennych starego miasta, przywracająca ciągłość historycznej przestrzeni urbanistycznej, z kontynuacją zabudowy kwartałowej, o zwartym charakterze, na obszarach, które uległy erozji [7]. Zabieg ma mieć wpływ na uporządkowanie zabudowy, wyeksponowanie najbardziej reprezentacyjnych budowli i miejsc w Międzyrzeczu, w tym Rynku, wprowadzając ład przestrzenny. Szansą na podniesienie rangi zarówno Starego Miasta jak i samego Rynku jest odtworzenie historycznych linii zabudowy, gdzie jest to możliwe, a w szczególności wschodniej i południowej pierzei, gdzie dzisiaj znajduje się skwer, szalet miejski oraz parterowe pawilony i kioski o nieestetycznych i podniszczonych elewacjach.

Jednym z istotnych zadań rewitalizacji Starego Miasta jest odtworzenie placu rynkowego, w jego rozmiarach i przestrzennych proporcjach, jako podstawowej dominanty średniowiecznego planu miasta. Obecny Rynek ma całkowicie zniekształcone historyczne proporcje. Szczególnie odnosi się to do terenu na wschód i południowy wschód od Ryn$\mathrm{ku}$ - miejsca po dwóch kwartałach zabudowy, zniszczonych w wyniku wojny i ostatecznie rozebranych pod koniec lat 40 . XX w. Obecnie miejsce to wypełnia zieleń parku nazywanego przez mieszkańców dość pretensjonalnie „plantami” (Rys. 1). Wobec braku wschodniej pierzei oraz poważnych ubytków w pierzei południowej, kształt Rynku jest rozmyty i pozbawiony tradycyjnych ram przyrynkowej zabudowy. Powierzchnia placu rynkowego, przenikając się z zielenią parku, jest obecnie zafałszowana i nieokreślona. 
W koncepcji rewaloryzacji Rynku zaaranżowano:

- nową posadzkę, z fontanną, zielenią i małą architekturą,

- nową dyspozycję ruchu pieszego i kołowego,

- uzupełnienie zabudowy pierzei południowej,

- likwidację ,plant”,

- odtworzenie wschodniej pierzei Rynku wraz z całym kwartałem przyrynkowej zabudowy (Rys. 3, po lewej).
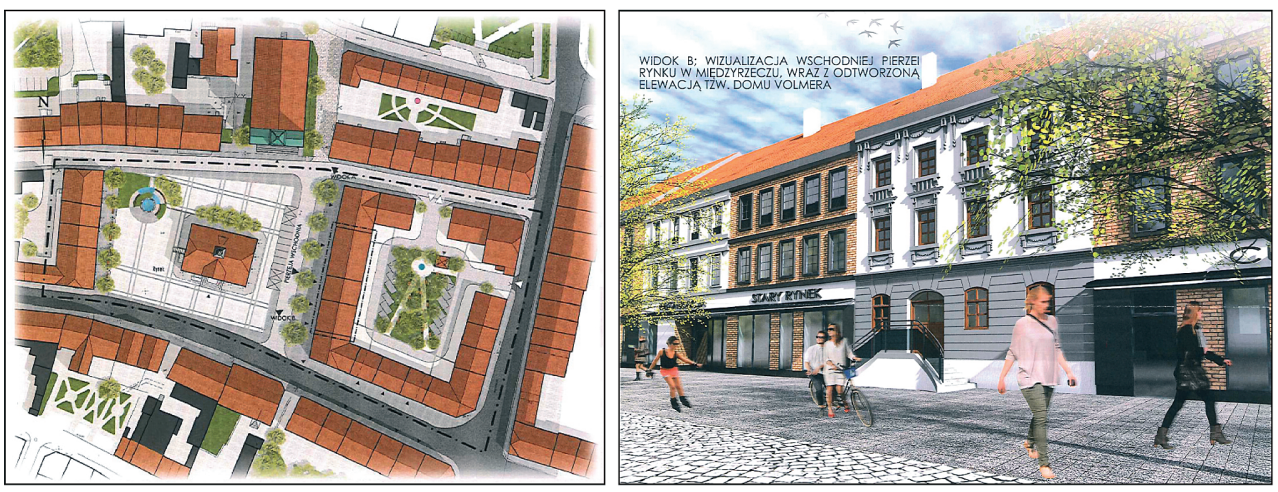

Rys. 3. (po lewej) Zagospodarowanie terenu wokół Starego Rynku; (po prawej) projekt wschodniej pierzei Rynku z repliką elewacji domu J. J. Volmera. Rys. Ilona Pisera

Zabudowę tego kwartału mają tworzyć trzykondygnacyjne domy, o funkcji mieszkaniowej z usługami w parterach, kryte wysokim dachem, o współczesnych formach, materiałach i detalu. Ciąg kamienic nowo projektowanej pierzei urozmaicono cytatem z historycznej architektury, odtwarzając, na podstawie archiwalnej dokumentacji, klasycystyczną elewację stojącego tu niegdyś domu należącego do kupca J.J. Volmera. (Rys. 3, po prawej). Kamienicę tę nazywano też „domem Napoleona”, ponieważ cesarz Francuzów stacjonował tu na początku XIX wieku, w swoim marszu na Wschód. Dyspozycja wnętrza i konstrukcja kamienicy Volmera zostały rozwiązane zgodnie ze współczesnymi wymogami zabudowy, odtworzona elewacja stanowi jedynie ozdobną aplikację, nawiązującą do historii miejsca. Do pamięci miejsca odnoszą się także nazwy nadane lokalom usługowym w trzech kamienicach tej pierzei, jak: „Restauracja Stary Rynek”, „Kawiarnia Volmer” i Cukiernia Napoleon”.

Pod względem komunikacyjnym założono zamknięcie placu rynkowego dla samochodów osobowych, z wyjątkiem pojazdów uprzywilejowanych i mieszkańców przylegających kwartałów. Do użytku publicznego interesantów kościoła, ratusza i lokali usługowych dopuszczono drogę dojazdową z parkingiem po wschodniej stronie placu rynkowego.

\section{Zakończenie}

Projekt rewitalizacji historycznego miasta wraz z kompleksem zamkowym w Międzyrzeczu, stanowi przykład kompleksowego opracowania konserwatorskiego od skali urbanistycznej do architektonicznej, bazującego na wytycznych konserwatorskich, będących efektem szerokich badań historyczno-urbanistycznych oraz przeprowadzonych analiz stanu istniejącego, w licznych aspektach (hipsometria terenu, uwarunkowania komunikacyjne i funkcjonalno-przestrzenne, analiza dokumentów planistycznych, ocena stanu technicznego 
oraz walorów estetycznych budynków i otoczenia, rozwarstwienie chronologiczne zabudowy). W ramach rewitalizacji m.in. uzupełniono brakujące kwartały zabudowy, zaprojektowano nową posadzkę w Rynku, ożywiono nową funkcją zabudowania folwarczne oraz zaprojektowano park krajobrazowy na sąsiadującym zdegradowanym terenie.

Zaprezentowany przykład wskazuje na konieczność podejmowania komplementarnych działań w procesie rewitalizacji historycznych miast.

\title{
Literatura
}

[1] Pisera I. Koncepcja rewaloryzacji Starego Miasta wraz z kompleksem zamkowym w Międzyrzeczu. Praca dyplomowa wykonana pod kier. Prof. W. Kononowicz w Katedrze Architektury i Urbanistyki WBAiIS na Uniwersytecie Zielonogórskim, Zielona Góra 2016.

[2] www.icomos-poland.org/pl/konkursy/konkurs-im-prof-jana-zachwatowicza/169-wynikikonkursu-im-prof-jana-zachwatowicza-2016.html

[3] Vademecum Konserwatora Zabytków. Międzynarodowe normy ochrony dziedzictwa kultury. Biuletyn ICOMOS, Warszawa 2015.

[4] Kłosek-Kozłowska D. Dziedzictwo miast. Ochrona i rozwój. PAN Warszawska Drukarnia Naukowa, Warszawa 2013.

[5] Polski Komitet Narodowy ICOMOS 1965-2015. 50 lat w stużbie ochrony zabytków, red. Pałubska K., Polski Komitet Narodowy ICOMOS, Muzeum Pałacu Króla Jana III w Wilanowie, Warszawa 2015.

[6] Tureczek M. Zabytki w krajobrazie kulturowym Międzyrzecza i okolic. Agencja Reklamowa BM Michał Górzny, publikacja na zlecenie Gminy Międzyrzecz, Międzyrzecz 2012.

[7] Paszkowski Z. Restrukturalizacja miasta historycznego. Hogben, Szczecin 2008.

\section{Small town revitalization issues on the example of Międzyrzecz}

\section{Wanda Kononowicz, Ilona Pisera}

Department of Architecture and Urban Planning,

Faculty of Engineering, Architecture and Environmental Engineering, University of Zielona Góra, e-mail:w.kononowicz@aiu.uz.zgora.pl,ilonapisera@gmail.com

\begin{abstract}
The article presents a method of revitalisation of the Old Town together with the castle and grange complex in Międzyrzecz, applied in a master's dissertation prepared at the Chair of Architecture and Urban Planning of University of Zielona Góra in 2016, that received an honourable mention in the Prof. Jan Zachwatowicz international conservation competition organised by PKN ICOMOS. The revitalisation method envisaged restoration of the general spatial characteristics of a historical urban scheme, permitting diversity of the supporting components being subordinated to the overall composition. The notion of diversity applies to the buildings protected by the monuments conservator as well as to the new ones harmonising with the existing environment and to reconstructions.
\end{abstract}


The eastern frontage and part of the southern frontage of the market place were destroyed by World War II and never rebuilt. Their place, as well as that of the adjacent dwelling quarters were taken by greenery. Majority of residents, especially the young ones accept this status quo.

The master's dissertation is an example of a comprehensive conservation study, from urban to architectural scale, preceded by historical-urban studies and relevant analyses of the existing state in many aspects. Results of the analyses enabled to formulate conclusions and conservation guidelines which served as the basis for the revitalisation design. The revitalisation included, amongst other things, rebuilding of the missing city blocks, preparation of a new floor design for the Market Place, revival of the grange complex buildings with new features and designing a landscape park to be situated on the adjacent, degraded land.

Keywords: revitalization, small town, Międzyrzecz. 